University at Albany, State University of New York

Scholars Archive

\title{
Reid's Dilemma and the uses of Pragmatism
}

\author{
P.D. Magnus \\ University at Albany, State University of New York, pmagnus@albany.edu
}

Follow this and additional works at: https://scholarsarchive.library.albany.edu/cas_philosophy_scholar

Part of the Philosophy Commons

\section{Recommended Citation}

Magnus, P.D., "Reid's Dilemma and the uses of Pragmatism" (2004). Philosophy Faculty Scholarship. 46. https://scholarsarchive.library.albany.edu/cas_philosophy_scholar/46

This Article is brought to you for free and open access by the Philosophy at Scholars Archive. It has been accepted for inclusion in Philosophy Faculty Scholarship by an authorized administrator of Scholars Archive. For more information, please contact scholarsarchive@albany.edu. 


\title{
Reid's dilemma and the uses of pragmatism
}

\author{
P.D. Magnus \\ Publshed in Journal of Scottish Philosophy, 2(1): 69-72. March 2004. \\ This penultimate draft of the paper is \\ available on-line at http://www.fecundity.com/job
}

\begin{abstract}
Peter Baumann offers the tantalizing suggestion that Thomas Reid is almost, but not quite, a pragmatist. He motivates this claim by posing a dilemma for common sense philosophy: Will it be dogmatism or scepticism? Baumann claims that Reid points to but does not embrace a pragmatist third way between these unsavory options. If we understand 'pragmatism' differently than Baumann does, however, we need not be so equivocal in attributing it to Reid. Reid makes what we could call an argument from practical commitment, and this is plausibly an instance of what William James calls the pragmatic method.
\end{abstract}

\section{The dilemma}

Peter Baumann [Bau99] suggests that Reid's common sense philosophy faces a dilemma. The dilemma develops in this way: Reid answers the sceptic by arguing that it is a matter of common sense (e.g.) that our senses teach us about an external world. Yet, as Reid is well aware, these principles of common sense could be false. Should we believe in them or not?

1st horn: We believe the principles of common sense. If we accept the burden of proving the beliefs, then we will run afoul of sceptical arguments and have to stop believing them. So we must accept the beliefs without proof. This is dogmatism, the scandal of philosophy that Kant bemoans wherein "the existence of things outside us... must be accepted merely on faith" [Kan29, p. Bxxxix fn.].

2nd horn: We do not believe the principles of common sense. We decline from making knowledge claims and thus avoid any justificatory burden. Yet this is to abdicate to scepticism.

The dilemma, then, is between dogmatism and scepticism. We either believe as we do without justification or we decline to believe. 


\section{Baumann's invocation of pragmatism}

Baumann sees Reid as aiming to find a third way between the horns of this dilemma. Reid acknowledges that first principles are not acquired by an exercise of reason. In a passage that Baumann cites approvingly, Reid writes: "Most men continue all their days to be just what Nature and human education made them. Their manners, their opinions, their virtues, and their vices, are all got by habit, imitation, and instruction; and reason has little or no share in forming them" [Inq, ch $6 \S 24$, p. 201]. ${ }^{1}$ If we acquire them without reason, then why should we need a reason to keep them?

Baumann calls this element of Reid's thinking a "pragmatic twist" [Bau99, p. 53]. He explicates it as an argument that asking for a theoretical justification of common sense principles is not merely asking too much, it is a meaningless question. The "pragmatic justification" goes like this:

To ask for reasons here is to fundamentally misunderstand what a first principle is. ... The principles of common sense enable us to build theories which guide our actions and let us attain our goals. Insofar as they fulfill this function, they are justified and there is no place for a different kind of justification, no need to talk about truth or knowledge. [Bau99, p. 53]

Baumann sees Reid as broaching but not developing a pragmatic justification of this kind.

The pragmatism here consists of two separable elements: First, a claim that it is meaningless to ask for justification of common sense principles. Second, a claim that we should accept principles of common sense because they get us what we want. Baumann sees the first element as charting the third way between the horns of the dilemma. If asking for justification makes no sense, then we needn't either claim to know or claim not to know that principles of common sense are true. Truth leaves the picture. As Baumann notes, this begins to sound like what Wittgenstein says in On Certainty [Wit69].

In one sense, the second element alone would be sufficient to answer the dilemma. We believe principles of common sense. If asked why we believe them, we can say that we have certain projects that are served by believing them. Yet this is subject to the usual objections against pragmatism. ${ }^{2}$ We say that "There is a world" is true, for instance, because we think believing in a world will prove to be advantageous. What justifies this further claim that "Believing 'There is a world' will prove advantageous"? We have no more way of proving that believing in a world will be useful than we have of proving that there is a world. Perhaps this is why Baumann thinks the pragmatic appeal to interest must be supplemented with a Wittgensteinian moratorium on truth talk. If we refuse to say that the principles of common sense are "true," then truth is at issue neither for the principle of common sense nor for its usefulness. The objection is evaded,

\footnotetext{
1'Inq' refers to Reid's Inquiry into the Human Mind of 1764. Page numbers refer to [Rei67].

${ }^{2}$ Russell expresses worries of this kind in his widely-influential discussion of the pragmatic theory of truth [Rus45, p. 817].
} 


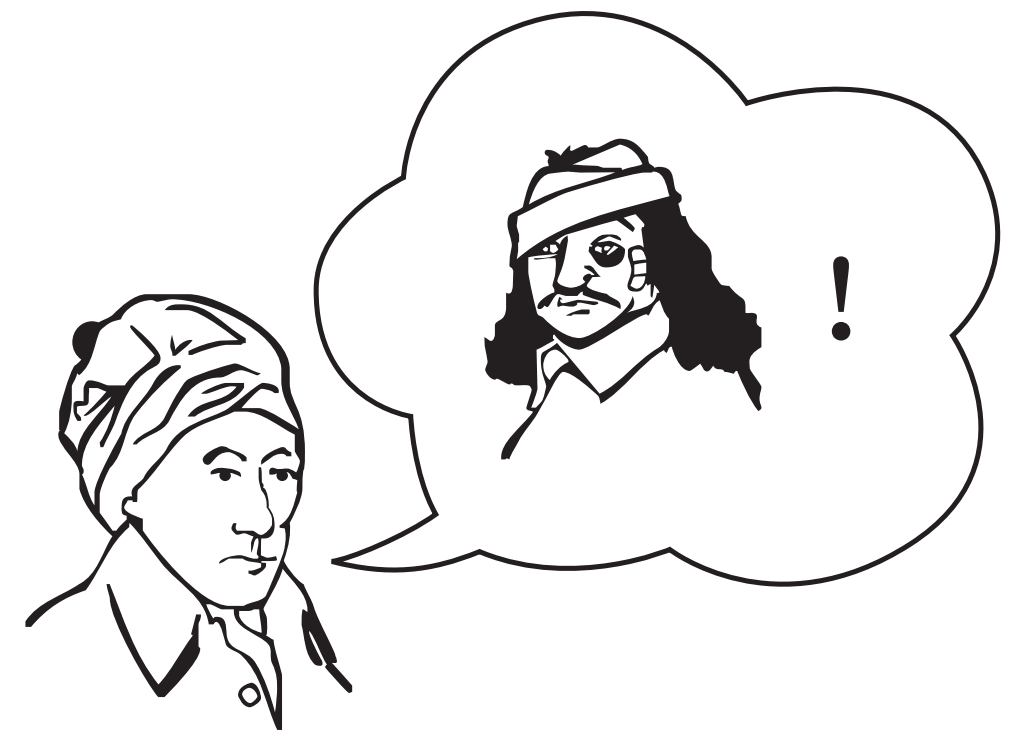

Figure 1: Reid argues that the sceptic, were he determined and consistent, would meet with tragedy.

but only for a moment: Even if the principles of common sense aren't subject to epistemic justification - they are neither "true" nor "false" - common sense must actually enable us to attain our goals if the pragmatic justification is to succeed. Either we must show that the principles of common sense will be useful, or we must accept it arbitrarily.

This is rather like the first horn of the dilemma, so I worry that this pragmatic justification does not resolve the dilemma after all. We might avoid being dogmatists or sceptics about common sense, but we would become dogmatists about the usefulness of common sense itself.

What relevance does this have to Reid? Baumann cautions, "To be sure: Reid... does not really talk about pragmatic justification" [Bau99, p. 53]. Yet Reid does make a kind of pragmatic move, one that is importantly more subtle.

\section{Reid's pragmatic answer to the sceptic}

Reid's appeal to common sense is not a direct answer to the determined sceptic. Reid concedes: "Perhaps the sceptic will agree to distrust reason, rather than give any credit to perception" [Inq, ch. $6 \S 20$, p. 183]. Although there is no utterly compelling reason why the sceptic should not do this, Reid goes on to offer three reasons why he and "the sober part of mankind" would not follow the sceptic in doing so.

The second reply concerns us here: Reid suggests that actually doubting the 
world, were such a thing possible, would only lead to disaster. Suppose, Reid says, "I resolve not to believe my senses. I break my nose against a post that comes in my way; I step into a dirty kennel; and, after twenty such wise rational actions, I am taken up and clapped in a madhouse" [Inq, ch. $6 \S 20$, p. 184]. There is a commitment in practice to the existence of an external world that contains many of the snares and pitfalls in which realists believe. This might be seen as the second element of Baumann's pragmatism: We believe because it furthers our goals of not breaking our noses, not stepping in kennels, and so on. However, Reid's argument is more subtle than this. He insists that sincere scepticism would undercut practical engagement with the world and thus that the so-called sceptic betrays a belief in the real world by managing their affairs just as common folk do: "If a man pretends to be a sceptic with regard to the informations of sense, and yet prudently keeps out of harm's way as other men do, he must excuse my suspicion, that he either acts the hypocrite, or imposes upon himself" [Inq, ch. $6 \S 20$, p. 184].

Reid argues that principles of common sense must be right if our everyday lives are to make any sense, but he cannot give an unconditional defense of our everyday lives. If sceptics see that their practice implies certain beliefs, then they are left with a choice of abstaining from their practice or accepting the beliefs. Reid's argument cannot force their choice, but it makes them pay a higher price if they cleave to scepticism. We might call this an argument from practical commitment. If sceptics navigate the world in the way you or I do, they already do believe in an external world. This is not subject to the usual objection against pragmatism, because it does not require sceptics to see that it would be in their interests to accept common sense. Sceptics are already engaged in certain practices that show that they already do accept common sense, whatever their verbal protestations to the contrary.

Thus, we can see Reid here as employing the pragmatic method without endorsing the pragmatic theory of truth. The distinction is due to William James, who specifies the pragmatic method: "Whenever a dispute is serious, we ought to be able to show some practical difference that must follow from one side or the other's being right" [Jam81, lec. II, p. 26]. Reid's argument respects this dictum: If scepticism is serious, then it binds the sceptic to whatever consequences for action there might be. If scepticism operates only in the drawing room, it amounts to nothing.

The argument works because so-called sceptics do not carry their scepticism out into the street, even when pressed. This is not a premise of the argument, but rather a precondition for applying it. We need not ask ersatz sceptics to assent to anything; we need only point at what they do. As C.S. Peirce remarks, "It has often been argued that absolute scepticism is self-contradictory; but this is a mistake." Rather, "there are no such beings as absolute sceptics" [Pei92, p. 56].

Baumann argues that Reid's theory leads to a dilemma which could be answered if only Reid indulged his pragmatist affinity. Reid does avoid the dilemma, in part with a pragmatist maneuver more subtle than the one Bau- 
mann suggests for him. ${ }^{3}$ Reid applies the pragmatic method to show that the would-be sceptic tacitly gives the lie to his scepticism by skillfully navigating the world.

\section{References}

[Bau99] Peter Baumann. The Scottish pragmatist? Reid Studies, 2(2):47-57, 1999.

[Jam81] William James. Pragmatism. Hackett, Indianapolis, [1907] 1981. Edited by Bruce Kuklick.

[Kan29] Immanuel Kant. Critique of Pure Reason. Macmillan \& Co., 1929. Translated by Norman Kemp Smith.

[Mag03] P.D. Magnus. Underdetermination and the Claims of Science. PhD thesis, University of California, San Diego, 2003.

[Pei92] Charles Sanders Peirce. Grounds of validity of the laws of logic: Further consequences of four incapacities. In Nathan Houser and Christian Kloesel, editors, The Essential Peirce, volume 1, pages 56-82. Indiana University Press, Bloomington, 1992.

[Rei67] Thomas Reid. Philosophical Works, volume I. George Olms Verlagsbuchhandlung, Hildesheim, 1967. Notes by Sir William Hamilton.

[Rus45] Bertrand Russell. A History of Western Philosophy. Simon and Schuster, 1945.

[Wit69] Ludwig Wittgenstein. On Certainty. Basil Blackwell, 1969. Edited by G.E.M. Anscombe \& G.H. von Wright. Translated by Denis Paul \& G.E.M. Anscombe.

\footnotetext{
${ }^{3}$ It should be remembered that this is the second of three replies to the sceptic. The other two are not so obviously pragmatist, so I leave them for another day. (See my [Mag03, ch. II].)
} 